\title{
Synthesis and Fluorescence Properties of Lower Rim Functionalized p-tert-Butyl Thiacalix[4]arenes Containing Anthraquinone and $N, N$-Diethylacetamide Fragments
}

\author{
Alena A. Vavilova, ${ }^{a}$ Roman V. Nosov, ${ }^{a}$ Anna N. Yagarmina, ${ }^{a}$ Olga A. Mostovaya, ${ }^{a}$ \\ Igor S. Antipin, ${ }^{a}$ Alexander I. Konovalov, a and Ivan I. Stoikov ${ }^{a}, \mathrm{~b}$
}

Dedicated to Academician Aslan Yu. Tsivadze on the occasion of his 70th Anniversary

\begin{abstract}
${ }^{a}$ Kazan (Volga Region) Federal University, A. M. Butlerov Chemical Institute, 420008 Kazan, Russian Federation
${ }^{\mathrm{b}}$ Kazan Institute of Biochemistry and Biophysics, Russian Academy of Sciences, 420111Kazan, Russian Federation

${ }^{\circledR}$ Corresponding author E-mail: ivan.stoikov@mail.ru
\end{abstract}

\begin{abstract}
It was shown that the chemo- and stereoselective alkylation of the lower rim 1,3-disubstituted p-tert-butyl thiacalix[4] arenes in the cone conformation using 2-chloro- $N, N$-diethylacetamide is determined by both the nature of the base and the position of the anthraquinone fragment in relation to the amide group: in the case of the 1-amidoanthraquinone derivative, tetrasubstituted products are produced, and in the case of the 2-amidoanthraquinone derivative, trisubstituted macrocycles are formed. It was established that the introduction of N, N-diethylacetamide fragments at the lower rim of 1,3-disubstituted macrocycles leads to an increase in the fluorescence intensity of the synthesized compounds.
\end{abstract}

Keywords: Thiacalix[4]arenes, synthesis, fluorescence spectroscopy.

\section{Синтез и флуоресцентные свойства функционализированных по

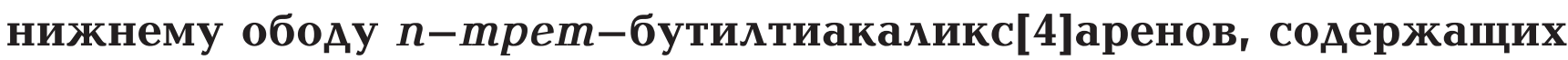 антрахиноновые и $N, N$-Аиэтилацетамидные фрагменты}

\author{
А. А. Вавилова, ${ }^{a}$ Р. В. Носов, ${ }^{a}$ А. Н. Ягармина, ${ }^{a}$ О. А. Мостовая, ${ }^{a}$ И. С. Антипин, ${ }^{a}$ \\ А. И. Коновалов, ${ }^{a}$ И. И. Стойков ${ }^{\mathrm{a}, \mathrm{b}}$
}

Посвящается акаgемику Аслану Юсуповичу Циваgзе по случаю его 70-летнего юбилея

${ }^{\mathrm{a}}$ Казанский (Приволжский) федеральный университет, Химический институт им. А.М. Бутлерова, 420008 Казань, Россия

${ }^{\mathrm{b}}$ ФББУН Казанский институт биохимии и биофизики РАН, 420111 Казань, Россия

${ }^{\circledR}$ E-mail: ivan.stoikov@mail.ru

\begin{abstract}
Показано, что хемо- и стереоселективность алкилирования 2-хлор-N,N-диэтилацетамидом 1,3-дизамещенных по нижнему ободу n-трет-бутилтиакаликс[4]аренов в конформации конус определяется как природой используемого основания, так и положением антрахинонового фрагмента относительно амидной группы: в случае 1-амидоантрахинонового заместителя на нижнем ободе образуются тетразамещенные продукты, а в случае 2-амидоантрахинонового - тризамещенные макрочикль. Установлено, что введение $N, N$-диэтилацетамидных фрагментов в нижний обод 1,3-дизамещенных макрочииков ведет к возрастанию интенсивности флуоресиенции синтезированных соединений.
\end{abstract}

Ключевые слова: Тиакаликс[4]арены, синтез, флуоресцентная спектроскопия. 


\section{Introduction}

It is well known that the (thia)calix[4]arene macrocyclic platform is used for the synthesis of fluorescent probes for different types of anions, cations and neutral molecules. ${ }^{[1-3]}$ The common mechanism employed in fluorescent sensor systems based on (thia)calix[4]arene is photoinduced electron transfer (PET). Concurrently, excimer complexes may also form. ${ }^{[1]}$ For the realization of PET mechanism in such sensors, the initial macrocyclic platform of (thia) calix [4]arene is usually modified by reagents with condensed systems (anthranyl, naphthyl fragments) having electron acceptor atoms such as $\mathrm{N}$ or $\mathrm{O} .{ }^{[4-6]}$ It should be noted that often in such fluorescent probes, differently substituted thiacalix[4]arene derivatives in which fluorescent markers as well as different functional groups which confers additional properties on the macrocycle, are employed.

Previously, a successful selective 1,3-dialkylation of the lower rim $p$-tert-butyl thiacalix[4]arene with 2-bromo$N$-(9',10'-dioxo-9', 10'-dihydroanthracene-1'-yl)acetamide or 2-bromo- $N$-(9',10'-dioxo-9', 10'-dihydroanthracene-2'yl)acetamide ${ }^{[7]}$ was performed in an attempt to develop new approaches for the synthesis of heterofunctionalized synthetic receptors. In this respect, it was interesting to investigate the conditions for the further functionalization of the macrocycles $\mathbf{2}$ and $\mathbf{3}$ by $N, N$-diethylacetamide fragments, which are known to bind cationic substrates. ${ }^{[8]}$

\section{Experimental}

\section{General}

${ }^{1} \mathrm{H}$ NMR spectra were recorded on a Bruker Avance-400 (400 $\mathrm{MHz}$ ) spectrometer and ${ }^{13} \mathrm{C}$ and $2 \mathrm{D}$ NOESY NMR spectra were obtained on an impulse spectrometer Bruker Avance II (with 125 $\mathrm{MHz}$ and $500 \mathrm{MHz}$ respectively). Chemical shifts were determined relative to the signals of residual protons of deuterated solvent $\left(\mathrm{CDCl}_{3}\right)$. The concentration of sample solutions was 3-5\%.

Attenuated total internal reflectance IR spectra were recorded with Spectrum 400 (Perkin Elmer) Fourier spectrometer.

Fluorescence spectra were recorded on a Fluorolog 3 luminescent spectrometer (Horiba Jobin Yvon). The excitation wavelengths were selected as $410 \mathrm{~nm}$ for compounds $\mathbf{2}$ and $\mathbf{5}, 435 \mathrm{~nm}$ for compound 3, $380 \mathrm{~nm}$ for compound 6 and $385 \mathrm{~nm}$ for compound 7. The emission scan range were $430-650 \mathrm{~nm}$ for compounds $\mathbf{2 , 6}$ and 7 and $450-650 \mathrm{~nm}$ for compounds $\mathbf{3}$ and $\mathbf{5}$. Excitation and emission slits were $6 \mathrm{~nm}$. Quartz cuvettes with optical path length of $10 \mathrm{~mm}$ were used. Emission spectra were automatically corrected by the Fluoressence program. The fluorescence spectra were recorded for thiacalix[4]arenes in chloroform solutions with concentration $C=2.5 \cdot 10^{-5} \mathrm{M}$. The experiment was carried out at $25^{\circ} \mathrm{C}$.

Elemental analysis was performed with Perkin Elmer 2400 Series II instrument.

Mass spectra were recorded with the MALDI-TOF Dynamo Finnigan (using 1,8,9-trihydroxyanthracene or 4-nitroaniline matrices).

Melting points were determined using the Boetius Block apparatus.

Additional control of the purity of compounds and monitoring of the reaction was carried out by thin-layer chromatography using Silica G, $200 \mu \mathrm{m}$ plates, UV 254.

5,11,17,23-Tetra-tert-butyl-25,27-dihydroxy-26,28bis $\left[N-\left(9^{\prime}, 10\right.\right.$ '-dioxo-9', 10'-dihydroanthracene-1 '-yl)-aminocarbonylmethoxy]-2,8,14,20-tetrathiacalix[4]arene (2) and 5,11,17,23-tetra-tert-butyl-25,27-dihydroxy-26,28-bis[N-(9',10'- dioxo-9',10'-dihydroanthracene-2 '-yl)-aminocarbonylmethoxy]2,8,14,20-tetrathiacalix [4]arene (3) were synthesized as previously described. ${ }^{[7]}$

General procedure for the preparation of compounds 4 and 5 . p-tert-Butyl thiacalix[4] arene $2(0.50 \mathrm{~g}, 0.40 \mathrm{mmol})$ was suspended in $40 \mathrm{ml}$ of acetone containing anhydrous $\mathrm{Na}_{2} \mathrm{CO}_{3}(0.17 \mathrm{~g}, 1.60$ mmol) or anhydrous $\mathrm{K}_{2} \mathrm{CO}_{3}(0.22 \mathrm{~g}, 1.60 \mathrm{mmol})$. To the obtained suspension, 2-chloro- $N, N$-diethylacetamide $(0.22 \mathrm{ml}, 1.60 \mathrm{mmol})$ in $20 \mathrm{ml}$ of acetone was added. The reaction mixture was stirred while refluxing for $100\left(\mathrm{Na}_{2} \mathrm{CO}_{3}\right)$ or $20\left(\mathrm{~K}_{2} \mathrm{CO}_{3}\right)$ hours. The reaction was monitored by TLC. After cooling, in the first case $\left(\mathrm{Na}_{2} \mathrm{CO}_{3}\right)$, the residue from the reaction mixture was filtered off, dissolved in chloroform and washed with distilled water. The organic phase was separated, dried over $3 \AA$ molecular sieves. The solvent was removed under reduced pressure. The filtrate of the reaction mixture was evaporated on a rotary evaporator under reduced pressure. The residue was dissolved in chloroform and $20 \mathrm{ml}$ of ethanol was added. The parent thiacalix[4]arene 2 was obtained $(0.22 \mathrm{~g})$ and was filtered off. The filtrate was evaporated on a rotary evaporator and the residue was recrystallized from methanol and chloroform. Tetrasubstituted product $40.23 \mathrm{~g}(40 \%)$ was obtained. In the second case $\left(\mathrm{K}_{2} \mathrm{CO}_{3}\right)$, the residue from the reaction mixture was filtered off, the filtrate of reaction mixture was evaporated on a rotary evaporator under reduced pressure. The residue was dissolved in chloroform and washed with $2 \mathrm{M} \mathrm{HCl}$. The organic phase was separated, dried over $3 \AA$ molecular sieves. The solvent was removed under reduced pressure. The residue was recrystallized from THF and methanol. Tetrasubstituted product $50.20 \mathrm{~g} \mathrm{(34 \% )}$ was obtained.

5,11,17,23-Tetra-tert-butyl-25,27-bis [N-(9',10'-dioxo9',10'-dihydroanthracene-1 '-yl)-aminocarbonylmethoxy]26,28-bis[N,N-diethylaminocarbonylmethoxy]-thiacalix[4]arene (cone-4). Yield $0.23 \mathrm{~g}(40 \%)$. m.p. $213{ }^{\circ} \mathrm{C}$. ${ }^{1} \mathrm{H} \mathrm{NMR}\left(\mathrm{CDCl}_{3}\right) \delta_{\mathrm{H}}$ ppm: $0.98 \mathrm{t}\left(6 \mathrm{H},-\mathrm{N}-\mathrm{CH}_{2}-\mathrm{CH}_{3},{ }^{3} \mathrm{~J}_{\mathrm{HH}}=7.0 \mathrm{~Hz}\right) ; 1.07 \mathrm{~s}\left(18 \mathrm{H},\left(\mathrm{CH}_{3}\right)_{3} \mathrm{C}\right)$; $1.13 \mathrm{t}\left(6 \mathrm{H},-\mathrm{N}-\mathrm{CH}_{2}-\mathrm{CH}_{3},{ }^{3} \mathrm{~J}_{\mathrm{HH}}=7.0 \mathrm{~Hz}\right) ; 1.19 \mathrm{~s}\left(18 \mathrm{H},\left(\mathrm{CH}_{3}\right)_{3} \mathrm{C}\right)$; 3.22 q $\left(4 \mathrm{H},-\mathrm{N}-\mathrm{CH}_{2}-\mathrm{CH}_{3},{ }_{3} J_{\mathrm{HH}}=7.0 \mathrm{~Hz}\right) ; 3.40$ q $\left(4 \mathrm{H},-\mathrm{N}-\mathrm{CH}_{2}-\mathrm{CH}_{3}\right.$, $\left.{ }^{3} J_{\mathrm{HH}}=7.0 \mathrm{~Hz}\right) ; 5.30 \mathrm{~s}\left(4 \mathrm{H},-\mathrm{O}-\mathrm{CH}_{2}-\mathrm{NH}\right) ; 5.64 \mathrm{~s}\left(4 \mathrm{H},-\mathrm{O}-\mathrm{CH}_{2}-\mathrm{C}(\mathrm{O})\right.$ $\left.\mathrm{N}(\mathrm{Et}))_{2}\right) ; 7.30 \mathrm{~s}(4 \mathrm{H}, \mathrm{Ar}-\mathrm{H}) ; 7.46 \mathrm{~s}(4 \mathrm{H}, \mathrm{Ar}-\mathrm{H}) ; 7.55-8.15 \mathrm{~m}(14 \mathrm{H}$, $\mathrm{Ar}-\mathrm{H}) ; 12.59 \mathrm{~s}(2 \mathrm{H}, \mathrm{NH}) .{ }^{13} \mathrm{C} \mathrm{NMR}\left(\mathrm{CDCl}_{3}\right) \delta_{\mathrm{C}} \mathrm{ppm}: 12.96 ; 14.43$; $31.16 ; 122.70 ; 126.72 ; 127.14 ; 127.30 ; 129.13 ; 129.51 ; 133.98$; $134.09 ; 134.46 ; 134.57 ; 134.99 ; 169.40$. Spectrum ${ }^{1} \mathrm{H}^{1} \mathrm{H}$ NOESY (the most important cross-peaks): $\mathrm{H}^{1} / \mathrm{H}^{1}, \mathrm{H}^{\gamma^{\prime}} / \mathrm{H}^{9}, \mathrm{H}^{\gamma^{\gamma}} / \mathrm{H}^{10}, \mathrm{H}^{\gamma^{\prime}} /$ $\mathrm{H}^{11}$. MALDI-TOF MS: calculated $\left[\mathrm{M}^{+}\right] \mathrm{m} / \mathrm{z}=1472.5$, found $\mathrm{m} / \mathrm{z}$ $=1495.3[\mathrm{M}+\mathrm{Na}]^{+}$. Found: C 68.15, H 6.10, N 3.66, S $8.86 \%$. Calculated for $\mathrm{C}_{84} \mathrm{H}_{88} \mathrm{~N}_{4} \mathrm{O}_{12} \mathrm{~S}_{4}$ : C 68.45, H 6.02, N 3.80, S 8.70\%.

5,11,17,23-Tetra-tert-butyl-25,27-bis[N-(9',10'-dioxo9',10'-dihydroanthracene-1'-yl)-aminocarbonylmethoxy]-26,28bis $[N, N$-diethylaminocarbonylmethoxy]-thiacalix [4]arene $\quad(1,3-$ alternate-5). Yield $0.20 \mathrm{~g}(34 \%)$. m.p: $198^{\circ} \mathrm{C} .{ }^{1} \mathrm{H} \mathrm{NMR}\left(\mathrm{CDCl}_{3}\right) \delta_{\mathrm{H}}$ ppm: $1.02 \mathrm{t}\left(6 \mathrm{H},-\mathrm{N}-\mathrm{CH}_{2}-\mathrm{CH}_{3},{ }^{3} \mathrm{~J}_{\mathrm{HH}}=7.0 \mathrm{~Hz}\right) ; 1.11 \mathrm{~s}\left(18 \mathrm{H},\left(\mathrm{CH}_{3}\right)_{3} \mathrm{C}\right)$; $1.16 \mathrm{t}\left(6 \mathrm{H},-\mathrm{N}-\mathrm{CH}_{2}-\mathrm{CH}_{3},{ }^{3}{ }_{\mathrm{HH}}=7.0 \mathrm{~Hz}\right) ; 1.31 \mathrm{~s}\left(18 \mathrm{H},\left(\mathrm{CH}_{3}\right)_{3} \mathrm{C}\right)$; $3.22 \mathrm{q}\left(4 \mathrm{H},-\mathrm{N}-\mathrm{CH}_{2}-\mathrm{CH}_{3},{ }^{3} \mathrm{~J}_{\mathrm{HH}}=7.0 \mathrm{~Hz}\right) ; 3.41 \mathrm{q}\left(4 \mathrm{H},-\mathrm{N}-\mathrm{CH}_{2}-\mathrm{CH}_{3}\right.$, $\left.{ }^{3} J_{\mathrm{HH}}=7.0 \mathrm{~Hz}\right) ; 3.93 \mathrm{~s}\left(4 \mathrm{H},-\mathrm{O}-\mathrm{CH}_{2}-\mathrm{NH}\right) ; 4.82 \mathrm{~s}\left(4 \mathrm{H},-\mathrm{O}-\mathrm{CH}_{2}-\mathrm{C}(\mathrm{O})\right.$ $\left.\mathrm{N}(\mathrm{Et})_{2}\right) ; 7.50 \mathrm{~s}(4 \mathrm{H}, \mathrm{Ar}-\mathrm{H}) ; 7.68 \mathrm{~s}(4 \mathrm{H}, \mathrm{Ar}-\mathrm{H}) ; 7.70-9.30 \mathrm{~m}(14 \mathrm{H}$, $\left.\mathrm{Ar}{ }^{\prime}-\mathrm{H}\right) ; 12.57 \mathrm{~s}(2 \mathrm{H}, \mathrm{NH}) .{ }^{13} \mathrm{C} \mathrm{NMR}\left(\mathrm{CDCl}_{3}\right) \delta_{\mathrm{C}} \mathrm{ppm}: 13.67 ; 31.05$; $34.22 ; 40.52 ; 69.63 ; 120.51 ; 127.25 ; 128.40 ; 131.99 ; 133.38$; $134.14 ; 134.66 ; 141.52 ; 146.51 ; 156.40 ; 167.40 ; 184.57$. Spectrum ${ }^{1} \mathrm{H}-{ }^{1} \mathrm{H}$ NOESY (the most important cross-peaks): $\mathrm{H}^{1} / \mathrm{H}^{7}, \mathrm{H}^{1} / \mathrm{H}^{10}$, $\mathrm{H}^{1^{\prime} / \mathrm{H}^{11}}$. IR $v \mathrm{~cm}^{-1}$ : $3198(\mathrm{NH}) ; 1701\left(\mathrm{C}(\mathrm{O})-\mathrm{NEt}_{2}\right) ; 1675,1650,1578$ (C(O)-NH); 1152, 1054 (Ar-H). MALDI-TOF MS: calculated [M+] $m / z=1472.5$, found $[\mathrm{M}+\mathrm{H}]^{+} m / z=1473.3$. Found: $\mathrm{C} 68.73, \mathrm{H} 6.24$, N 3.95, S $8.94 \%$. Calculated for $\mathrm{C}_{84} \mathrm{H}_{88} \mathrm{~N}_{4} \mathrm{O}_{12} \mathrm{~S}_{4}$ : C 68.45, H 6.02, N 3.80 , S $8.70 \%$.

General procedure for the preparation of compounds 6 and 7 . p-tert-Butyl thiacalix[4]arene $3(0.50 \mathrm{~g}, 0.40 \mathrm{mmol})$ was suspended in $40 \mathrm{ml}$ of acetone containing anhydrous $\mathrm{Na}_{2} \mathrm{CO}_{3}(0.17 \mathrm{~g}, 1.60$ mmol) or anhydrous $\mathrm{K}_{2} \mathrm{CO}_{3}(0.22 \mathrm{~g}, 1.60 \mathrm{mmol})$ or anhydrous $\mathrm{Cs}_{2} \mathrm{CO}_{3}(0.52 \mathrm{~g}, 1.60 \mathrm{mmol})$. To the obtained suspension, 2-chloro$\mathrm{N}, \mathrm{N}$-diethylacetamide $(0.22 \mathrm{ml}, 1.60 \mathrm{mmol})$ in $20 \mathrm{ml}$ of acetone 
was added. The reaction mixture was stirred while refluxing for 50 $\left(\mathrm{Na}_{2} \mathrm{CO}_{3}, \mathrm{~K}_{2} \mathrm{CO}_{3}\right)$ or $30\left(\mathrm{Cs}_{2} \mathrm{CO}_{3}\right)$ hours. The reaction was monitored by TLC. After cooling, the residue from the reaction mixture was filtered off, the filtrate of reaction mixture was evaporated on a rotary evaporator under reduced pressure. The residue was dissolved in chloroform and washed with $2 \mathrm{M} \mathrm{HCl}$. The organic phase was separated, dried over $3 \AA$ molecular sieves. The solvent was removed under reduced pressure. The residue was recrystallized from THF and methanol. Trisubstituted product $60.29 \mathrm{~g} \mathrm{(53 \% )} \mathrm{or}$ $0.34 \mathrm{~g}(63 \%)$ was obtained when $\mathrm{Na}_{2} \mathrm{CO}_{3}$ or $\mathrm{K}_{2} \mathrm{CO}_{3}$ respectively were used. Also $0.25 \mathrm{~g}$ (46\%) of macrocycle 7 was isolated when $\mathrm{Cs}_{2} \mathrm{CO}_{3}$ was used.

5,11,17,23-Tetra-tert-butyl-25-hydroxy-26,28-bis[N-(9',10'dioxo-9',10'-dihydroanthracene-2'-yl)-aminocarbonylmethoxy]27-[N,N-diethylaminocarbonylmethoxy]-thiacalix [4]arene (cone-6). Yield $0.29 \mathrm{~g}(53 \%)$ or $0.34 \mathrm{~g}(63 \%)$. m.p. $234{ }^{\circ} \mathrm{C} .{ }^{1} \mathrm{H}$ NMR $\left(\mathrm{CDCl}_{3}\right) \delta_{\mathrm{H}} \mathrm{ppm}: 0.70 \mathrm{~s}\left(9 \mathrm{H},\left(\mathrm{CH}_{3}\right)_{3} \mathrm{C}\right) ; 1.05 \mathrm{~s}\left(9 \mathrm{H},\left(\mathrm{CH}_{3}\right)_{3} \mathrm{C}\right)$; $1.24 \mathrm{t}\left(3 \mathrm{H},-\mathrm{N}-\mathrm{CH}_{2}-\mathrm{CH}_{3},{ }^{3} \mathrm{~J}_{\mathrm{HH}}=7.0 \mathrm{~Hz}\right) ; 1.34 \mathrm{t}\left(3 \mathrm{H},-\mathrm{N}-\mathrm{CH}_{2}-\mathrm{CH}_{3}\right.$, $\left.{ }^{3} J_{\mathrm{HH}}=7.0 \mathrm{~Hz}\right) ; 1.39 \mathrm{~s}\left(18 \mathrm{H},\left(\mathrm{CH}_{3}\right)_{3} \mathrm{C}\right) ; 3.28 \mathrm{q}\left(2 \mathrm{H},-\mathrm{N}-\mathrm{CH}_{2}-\mathrm{CH}_{3}\right.$, $\left.{ }^{3} J_{\mathrm{HH}}=7.0 \mathrm{~Hz}\right) ; 3.67 \mathrm{q}\left(2 \mathrm{H},-\mathrm{N}-\mathrm{CH}_{2}-\mathrm{CH}_{3},{ }^{3} J_{\mathrm{HH}}=7.0 \mathrm{~Hz}\right) ; 4.73 \mathrm{~d}(2 \mathrm{H},-$ $\left.\left.\mathrm{O}-\mathrm{CH}_{2}-\mathrm{NH},{ }^{2} \mathrm{~J}_{\mathrm{HH}}=15.4 \mathrm{~Hz}\right) ; 4.79 \mathrm{~s}\left(2 \mathrm{H},-\mathrm{O}-\mathrm{CH}_{2}-\mathrm{C}(\mathrm{O}) \mathrm{N}(\mathrm{Et})\right)_{2}\right) ; 6.43$ d $\left(2 \mathrm{H},-\mathrm{O}-\mathrm{CH}_{2}-\mathrm{NH},{ }^{2} \mathrm{~J}_{\mathrm{HH}}=15.4 \mathrm{~Hz}\right) ; 6.78 \mathrm{~s}(2 \mathrm{H}, \mathrm{Ar}-\mathrm{H}) ; 7.72,7.82$ $\mathrm{AB}$ system $\left(4 \mathrm{H}, \mathrm{Ar}-\mathrm{H}_{\mathrm{A}}, \mathrm{Ar}-\mathrm{H}_{\mathrm{B}},{ }^{4} \mathrm{~J}_{\mathrm{HH}}=2.6 \mathrm{~Hz}\right) ; 8.00 \mathrm{~s}(2 \mathrm{H}, \mathrm{Ar}-\mathrm{H})$; 7.50-8.54 m (14H, Ar'-H); $9.64 \mathrm{~s}(1 \mathrm{H}, \mathrm{OH}) ; 10.94 \mathrm{~s}(2 \mathrm{H}, \mathrm{NH}) .{ }^{13} \mathrm{C}$ NMR $\left(\mathrm{CDCl}_{3}\right) \delta_{\mathrm{C}}$ ppm: $13.04 ; 14.27 ; 30.68 ; 31.07 ; 31.34 ; 33.89$; $34.38 ; 41.27 ; 41.47 ; 73.53 ; 74.53 ; 116.93 ; 120.35 ; 124.62 ; 126.72$; $126.89 ; 127.50 ; 128.28 ; 128.50 ; 128.64 ; 130.23 ; 132.85 ; 133.13$; $133.34 ; 133.46 ; 134.10 ; 134.92 ; 135.40 ; 136.65 ; 142.68 ; 143.72$; $146.99 ; 148.40 ; 155.44 ; 155.96 ; 159.77 ; 166.34 ; 169.07 ; 181.83$; 182.18. Spectrum ${ }^{1} \mathrm{H}-{ }^{1} \mathrm{H}$ NOESY (the most important cross-peaks): $\mathrm{H}^{4} / \mathrm{H}^{4}, \mathrm{H}^{7} / \mathrm{H}^{7}, \mathrm{H}^{1} / \mathrm{H}^{1}, \mathrm{H}^{\gamma^{\prime}} / \mathrm{H}^{10}$. IR $v \mathrm{~cm}^{-1}$ : 3286, $3196(\mathrm{NH}) ; 3113$ $(\mathrm{OH}) ; 1694$ (C(O)-NEt $)$ ); 1673, 1637, 1590 (C(O)-NH); 1154, 1095 (Ar-H). MALDI-TOF MS: calculated $\left[\mathrm{M}^{+}\right] \mathrm{m} / z=1359.4$, found $[\mathrm{M}+\mathrm{H}]^{+} m / z=1360.4$. Found: $\mathrm{C} 66.54, \mathrm{H} 6.12, \mathrm{~N} 4.26, \mathrm{~S} 9.46 \%$. Calculated for $\mathrm{C}_{78} \mathrm{H}_{77} \mathrm{~N}_{3} \mathrm{O}_{11} \mathrm{~S}_{4}$ : C 66.83, H 5.77, N 4.30, S 9.70\%.

5,11,17,23-Tetra-tert-butyl-25-hydroxy-26,28-bis [N-(9',10'dioxo-9',10'-dihydroanthracene-2'-yl)-aminocarbonylmethoxy]27-[N,N-diethylaminocarbonylmethoxy]-thiacalix[4]arene (partial cone-7). Yield $0.25 \mathrm{~g}(46 \%)$. m.p. $256^{\circ} \mathrm{C} .{ }^{1} \mathrm{H} \mathrm{NMR}\left(\mathrm{CDCl}_{3}\right) \delta_{\mathrm{H}} \mathrm{ppm}$ : $0.31 \mathrm{t}\left(3 \mathrm{H},-\mathrm{N}-\mathrm{CH}_{2}-\mathrm{CH}_{3},{ }^{3} \mathrm{~J}_{\mathrm{HH}}=7.0 \mathrm{~Hz}\right) ; 1.10 \mathrm{t}\left(6 \mathrm{H},-\mathrm{N}-\mathrm{CH}_{2}-\mathrm{CH}_{3}\right.$, $\left.{ }^{3} J_{\mathrm{HH}}=7.0 \mathrm{~Hz}\right) ; 1.16 \mathrm{~s}\left(9 \mathrm{H},\left(\mathrm{CH}_{3}\right)_{3} \mathrm{C}\right) ; 1.19 \mathrm{~s}\left(18 \mathrm{H},\left(\mathrm{CH}_{3}\right)_{3} \mathrm{C}\right) ; 1.34 \mathrm{~s}$ $\left(9 \mathrm{H},\left(\mathrm{CH}_{3}\right)_{3} \mathrm{C}\right) ; 2.89 \mathrm{q}\left(2 \mathrm{H},-\mathrm{N}-\mathrm{CH}_{2}-\mathrm{CH}_{3},{ }^{3} \mathrm{JH}_{\mathrm{HH}}=7.0 \mathrm{~Hz}\right) ; 3.30 \mathrm{q}(4 \mathrm{H}$, $\left.-\mathrm{N}-\mathrm{CH}_{2}-\mathrm{CH}_{3},{ }^{3} J_{\mathrm{HH}}=7.0 \mathrm{~Hz}\right) ; 4.58 \mathrm{~d}\left(2 \mathrm{H},-\mathrm{O}-\mathrm{CH}_{2}-\mathrm{NH},{ }^{2} J_{\mathrm{HH}}=15.0 \mathrm{~Hz}\right)$; $4.77 \mathrm{~s}\left(2 \mathrm{H},-\mathrm{O}-\mathrm{CH}_{2}-\mathrm{C}(\mathrm{O}) \mathrm{N}(\mathrm{Et})_{2}\right) ; 5.13 \mathrm{~d}\left(2 \mathrm{H},-\mathrm{O}-\mathrm{CH}_{2}-\mathrm{NH},{ }^{2} \mathrm{~J}_{\mathrm{HH}}=15.0\right.$ $\mathrm{Hz}) ; 7.45,8.14 \mathrm{AB}$ system $\left(4 \mathrm{H}, \mathrm{Ar}-\mathrm{H}_{\mathrm{A}}, \mathrm{Ar}-\mathrm{H}_{\mathrm{B}},{ }^{4} \mathrm{~J}_{\mathrm{HH}}=1.9 \mathrm{~Hz}\right) ; 7.75$ $\mathrm{s}(2 \mathrm{H}, \mathrm{Ar}-\mathrm{H}) ; 7.79 \mathrm{~s}(2 \mathrm{H}, \mathrm{Ar}-\mathrm{H}) ; 7.45-8.20 \mathrm{~m}(14 \mathrm{H}, \mathrm{Ar}$ '-H); 8.09 $\mathrm{s}(1 \mathrm{H}, \mathrm{OH}) ; 9.74 \mathrm{~s}(2 \mathrm{H}, \mathrm{NH}) .{ }^{13} \mathrm{C} \mathrm{NMR}\left(\mathrm{CDCl}_{3}\right) \delta_{\mathrm{C}} \mathrm{ppm}: 12.72$; $13.21 ; 30.98 ; 31.39 ; 34.45 ; 39.86 ; 41.00 ; 117.13 ; 121.19 ; 124.55$; $127.05 ; 127.11 ; 127.26 ; 128.77 ; 132.25 ; 132.87 ; 133.40 ; 133.68$; $133.94 ; 134.29 ; 135.12 ; 142.63 ; 144.39 ; 148.14 ; 148.78 ; 155.22$; $156.34 ; 158.03 ; 165.86 ; 181.68 ; 182.37$. Spectrum ${ }^{1} \mathrm{H}^{-1} \mathrm{H}$ NOESY (the most important cross-peaks): $\mathrm{H}^{1 /} / \mathrm{H}^{7}, \mathrm{H}^{7} / \mathrm{H}^{1}, \mathrm{H}^{10} / \mathrm{H}^{1}, \mathrm{H}^{11} / \mathrm{H}^{1}$. IR $v \mathrm{~cm}^{-1}$ : 3312, $3185(\mathrm{NH}) ; 3104(\mathrm{OH}) ; 1700\left(\mathrm{C}(\mathrm{O})-\mathrm{NEt}_{2}\right) ; 1673$, $1590(\mathrm{C}(\mathrm{O})-\mathrm{NH})$; 1174, 1085 (Ar-H). MALDI-TOF MS: calculated $\left[\mathrm{M}^{+}\right] m / z=1359.4$, found $[\mathrm{M}+\mathrm{H}]^{+} m / z=1360.6,[\mathrm{M}+\mathrm{Na}]^{+} \mathrm{m} / z=$ 1382.6. Found: C 66.42, H 6.00, N 4.17, S $9.65 \%$. Calculated for $\mathrm{C}_{78} \mathrm{H}_{77} \mathrm{~N}_{3} \mathrm{O}_{11} \mathrm{~S}_{4}: \mathrm{C} 66.83, \mathrm{H} 5.77, \mathrm{~N} 4.30$, S $9.70 \%$.

\section{Results and Discussion}

\section{Synthesis}

The $p$-tert-butyl thiacalix[4]arene macrocyclic platform is attractive because it is possible to obtain stereoisomers (cone, partial cone, 1,2-alternate and 1,3-alternate) of it with different spatial arrangement of functional groups. ${ }^{[9-17]}$
The current main objective, is the regioselective synthesis of partially substituted p-tert-butyl thiacalix[4]arene derivatives, with further functionalization which leads to differently substituted thiacalix[4]arenes with predetermined spatial orientation of binding sites.

Previously alkylating reagents containing the amidoanthraquinone fragment ${ }^{[7]}$ were used for the regioselective synthesis of lower rim 1,3-disubstituted thiacalix[4]arene derivatives $\mathbf{2}$ and $\mathbf{3}$ (Scheme 1). The 2-bromo- $N$-(9',10'-dioxo-9',10'-dihydroanthracene-1'-yl)acetamide and 2-bromo- $N$-(9',10'-dioxo-9',10'-dihydroanthracene-2'-yl)acetamide contain a polar NH group capable of interacting with anions, as well as a chromophoric fragment necessary for the detection of complex formation spectrophotometrically. In addition, the anthraquinone group is able to fluoresce, ${ }^{[18,19]}$ thus it would enable the detection substrate binding using fluorescence spectroscopy.

The influence of the conditions of alkylating macrocycles $\mathbf{2}$ and $\mathbf{3}$ on the stereo- and chemospecificity of the reaction have been studied with the aim of achieving differently substituted at the lower rim $p$-tert-butyl thiacalix[4]arenes. The interaction of $p$-tert-butyl thiacalix[4]arenes $\mathbf{2}$ and $\mathbf{3}$ with 2-chloro- $N, N$-diethylacetamide in acetone in the presence of alkali metal carbonates (Scheme 2 and 3), in particular, the influence of reaction conditions (time, the ratio of reactants, the nature of the base) on the chemo- and stereoselectivity of these reactions have been investigated. The base and solvent were chosen due to their efficiency in the alkylation reaction of lower rim $p$-tert-butyl thiacalix[4]arene. ${ }^{[20]}$ Alkali metal carbonates (sodium, potassium, cesium) were used as the base and acetone as solvent.

The reaction of macrocycle 2 with 2-chloro- $N, N$ diethylacetamide was carried out in the presence of various alkali metal carbonates in acetone at reflux. As a result of the interaction, $p$-tert-butyl thiacalix[4]arenes $\mathbf{4}$ and $\mathbf{5}$ tetrasubstituted at the lower rim were isolated in $40 \%$ and $34 \%$ yield, respectively (Scheme 2).

It should be noted that using sodium carbonate results in the cone stereoisomer $\mathbf{4}$, and using potassium carbonate results in the 1,3-alternate stereoisomer $\mathbf{5}$, which is obviously due to the template effect of the alkali metal cations. ${ }^{[20]}$

It should be noted that the reaction in the presence of $\mathrm{Cs}_{2} \mathrm{CO}_{3}$ resulted in a difficult to separate mixture of products, which was difficult to separate and characterize. Possibly, aside the phenolic hydroxyl groups, the secondary amide group $\mathrm{NH}$ also takes part in the reaction with 2-chloro- $\mathrm{N}, \mathrm{N}$ diethylacetamide. According to the ${ }^{1} \mathrm{H}$ NMR spectrum of thiacalix [4] arene 2, the amide NH proton signal is observed in weaker fields at $13.33 \mathrm{ppm}$ (Figure 1), which may attributed to the higher acidity and reactivity of the secondary amide group in macrocycle $\mathbf{2}$ compared to for example, the amide group of macrocycle 3 with chemical shift at $10.64 \mathrm{ppm}$ (Figure 1). Obviously, this is also due to the formation of intramolecular hydrogen bond between the amide proton and oxygen atom of the quinoid group and the formation of a stable six-membered ring.

In the interaction of macrocycle 3 with 2-chloro- $N, N$ diethylacetamide in the presence of sodium carbonate and potassium carbonate in acetone, the trisubstituted macrocycle 6 in the cone conformation was isolated with $53 \%$ and $63 \%$ yield, respectively (Scheme 3 ). By using cesium carbonate 
as a base, macrocycle 7 in the partial cone conformation was obtained with $46 \%$ yield (Scheme 3 ). Obviously, the formation of the partial cone conformation of thiacalix[4] arene 7 was stabilized by an intramolecular hydrogen bond between the hydroxyl proton and the neighboring oxygen atoms of the macrocycle, which is observed in the IR spectrum. The absorption bands of the valence vibrations of the NH bond of the 2-amidoanthraquinone fragment are observed as a narrow and broadened band at 3312 and 3185 $\mathrm{cm}^{-1}$ in the IR spectrum of compound 7 .

It turned out that the macrocycle $\mathbf{3}$ is less reactive than 2 . In the case of the macrocycle 2 , the interaction with 2-chloro- $N, N$-diethylacetamide in the presence of $\mathrm{K}_{2} \mathrm{CO}_{3}$ results in the formation of products after the first hour of the reaction (the extent of the reaction was monitored by TLC), and the total duration of synthesis was 20 hours. At the same time, in the case of the macrocycle $\mathbf{3}$, the total duration of the reaction was 50 hours while a significant amount of product formed only after 5 hours from the start of the reaction. Also, it is necessary to note that in the case of the macrocycle $\mathbf{3}$, even when a 20 fold excess of 2-chloro$\mathrm{N}, \mathrm{N}$-diethylacetamide and catalytic amounts of $\mathrm{KI}$ were used, only the trisubstituted product $\mathbf{6}$ was formed. Thus, the chemospecificity of alkylating 1,3-disubstituted macrocycles $\mathbf{2}$ and $\mathbf{3}$ with 2 -chloro- $N, N$-diethylacetamide is determined by the position of the anthraquinone fragment relative to the amide group (in position 1 or 2).

The structure and composition of the new thiacalix[4] arene derivatives 4-7 were characterized by NMR ${ }^{1} \mathrm{H},{ }^{13} \mathrm{C}$, 2D NOESY, IR spectroscopy, mass spectrometry (MALDITOF) and elemental analysis.

In the ${ }^{1} \mathrm{H}$ NMR spectrum of compound 6 (Figure 2), the signals of tert-butyl protons are observed as three singlets with an intensity ratio of 1:1:2 (0.70, 1.05 and $1.34 \mathrm{ppm})$, which confirms the formation of the trisubstituted product. The oxymethylene protons of the $N, N$-diethylacetamide substituent are observed as a singlet while the oxymethylene protons of the 2-amidoanthraquinone fragment as two doublets of AX-spin system (4.73 and $6.43 \mathrm{ppm}$ ) with a spin-spin interaction constant of $15.4 \mathrm{~Hz}$, which is due to their diastereotopicity and inequality in their surrounding substituents. The signals of the aromatic protons of the macrocycle are observed as two singlets $(6.78$ and 8.00 ppm) and two doublets of AB-spin system (7.72 and 7.82 ppm) with a spin-spin interaction constant of $2.6 \mathrm{~Hz}$, and the signals of the anthraquinone fragment as multiplets in

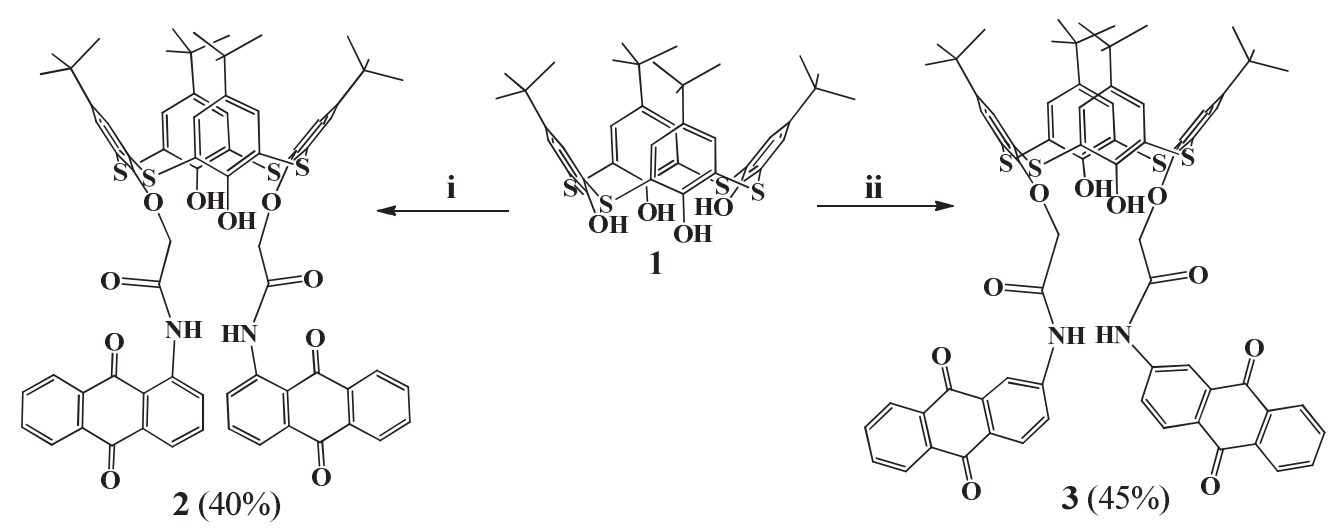

Scheme 1. Reagents and conditions: i, 2-bromo- $N$-(9',10'-dioxo-9', 10'-dihydroanthracene-1'-yl)acetamide/ $\mathrm{Na}_{2} \mathrm{CO}_{3}$, acetone, reflux; ii, 2-bromo- $N$-(9',10'-dioxo-9', 10'-dihydroanthracene-2'-yl)acetamide $/ \mathrm{Na}_{2} \mathrm{CO}_{3}$, acetone, reflux.

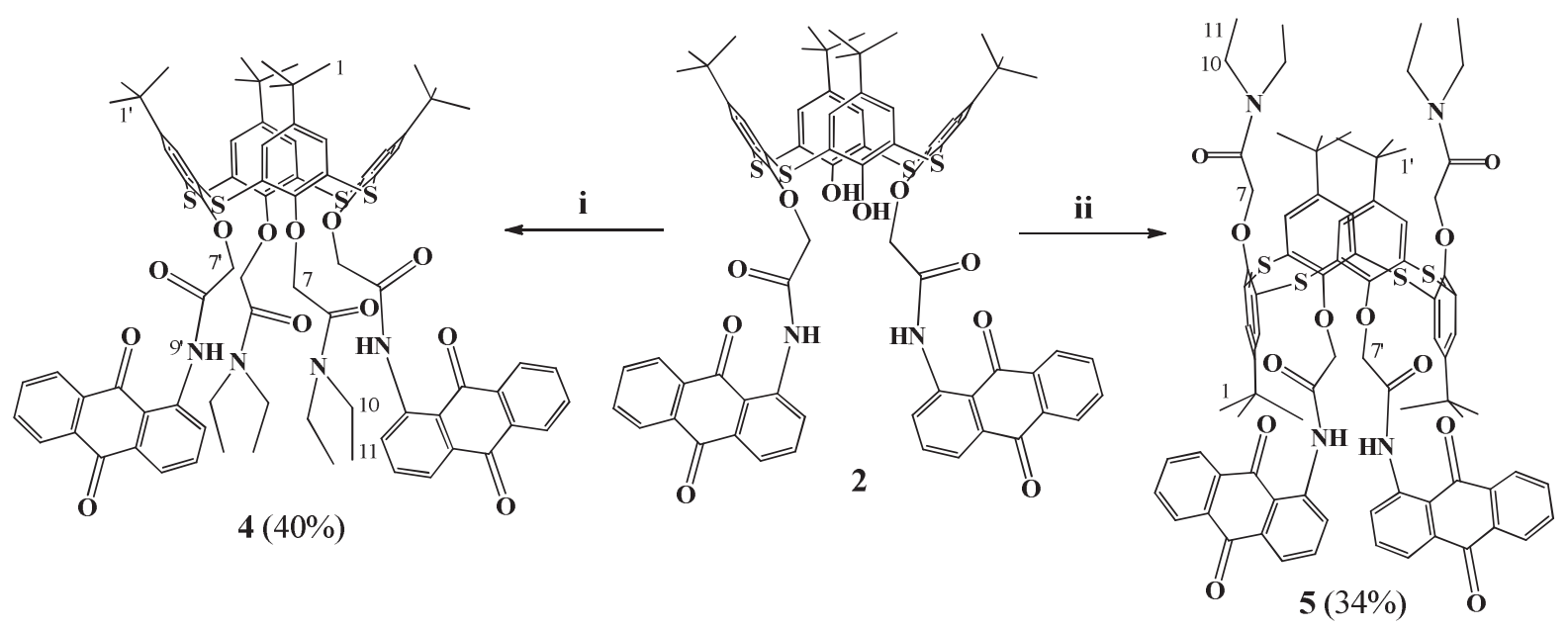

Scheme 2. Reagents and conditions: i, 2-chloro- $N, N$-diethylacetamide/ $\mathrm{Na}_{2} \mathrm{CO}_{3}$, acetone, reflux; ii, 2-chloro- $N, N$-diethylacetamide/ $\mathrm{K}_{2} \mathrm{CO}$, acetone, reflux. 
the field of 7.50-8.54 ppm. The signals of the hydroxyl and amide protons of compound $\mathbf{6}$ are observed in a weak field at 9.64 and $10.94 \mathrm{ppm}$ respectively. The chemical shifts, multiplicity and the integral intensity of the proton signals in ${ }^{1} \mathrm{H}$ NMR spectrum are in good agreement with the proposed structure of $p$-tert-butyl thiacalix[4] arene 6.

As an example, the mass spectrum of the lower rim trisubstituted $p$-tert-butyl thiacalix[4]arene 7 is shown in Figure 3.

In the MALDI-TOF mass spectrum of compound 7 $\left(\mathrm{M}\left(\mathrm{C}_{78} \mathrm{H}_{77} \mathrm{~N}_{3} \mathrm{O}_{11} \mathrm{~S}_{4}\right)=1359.4\right)$, the peaks of the molecular ion $\left(\mathrm{m} / \mathrm{z}\left(\mathrm{M}+\mathrm{H}^{+}\right)=1360.6\right)$ and the macrocycle with sodium cation $\left(m / z\left(\mathrm{M}+\mathrm{Na}^{+}\right)=1382.6\right)$ are presented.

Thus, the obtained thiacalix[4]arenes $\mathbf{4}$ and $\mathbf{6}$ are in the cone conformation while the $\mathbf{5}$ and $\mathbf{7}$ are in the 1,3-alternate and partial cone conformations respectively. The structure has been confirmed by 2D NOESY NMR spectroscopy. The presence of two proton singlets for the tert-butyl groups, two singlets for the oxymethylene protons and two singlets for the aromatic protons of the macrocycle in the ${ }^{1} \mathrm{H}$ NMR spectra of the lower rim heterofunctionalized tetrasubstituted p-tert-butyl thiacalix[4]arenes $\mathbf{4}$ and $\mathbf{5}$ shows the symmetry in the structures. However, in the ${ }^{1} \mathrm{H}$ NMR spectrum of trisubstituted thiacalix[4]arenes $\mathbf{6}$ and 7, the signals of the oxymethylene protons are observed as a singlet and an $\mathrm{AX}$ system due to diastereotopicity of $-\mathrm{O}-\mathrm{CH}_{2}$ - protons of the 2-amidoanthraquinone substituent. Also, the presence of hydroxyl proton signals at $9.64 \mathrm{ppm}$ and $8.09 \mathrm{ppm}$ in the ${ }^{1} \mathrm{H}$ NMR spectra of compounds 6 and 7, respectively, indicates an incomplete alkylation of the initial thiacalix[4]arene $\mathbf{3}$.

In the IR spectra of the obtained compounds, an absorption band for the valence vibrations of $N, N$ diethylacetamide group appears $\left(v, 1694-1701 \mathrm{~cm}^{-1}\right)$, which is absent in the parent thiacalix[4]arenes $\mathbf{2}$ and $\mathbf{3}$. Also in the IR spectra of trisubstituted thiacalix[4]arenes $\mathbf{6}$ and $\mathbf{7}$ in contrast to the tetrasubstituted thiacalix[4] arenes $\mathbf{4}$ and $\mathbf{5}$, an absorption band for the valence vibrations of the hydroxyl group ( $v, 3113$ and $3104 \mathrm{~cm}^{-1}$, respectively) is observed, indicating an incomplete substitution of the lower rim of the initial macrocycle $\mathbf{3}$.

Thus, new tri- and tetrasubstituted derivatives of thiacalix[4]arene containing 1- and 2-amidoanthraquinone and $N, N$-diethylacetamide fragments have been synthesized. The structure of the obtained compounds was characterized by ${ }^{1} \mathrm{H}$ NMR, ${ }^{13} \mathrm{C}$, IR spectroscopy and mass spectrometry (MALDI-TOF). The spatial structure of the new heterofunctionalized thiacalix[4]arenes was established by two-dimensional NMR spectroscopy, 2D NOESY ${ }^{1} \mathrm{H}-{ }^{1} \mathrm{H}$.

\section{Study of Fluorescence Properties}

It is known that anthraquinone groups are fluorophores. ${ }^{[18,19]}$ Therefore, the fluorescence properties of the obtained compounds were investigated (Figure 4). The initial com-

A)

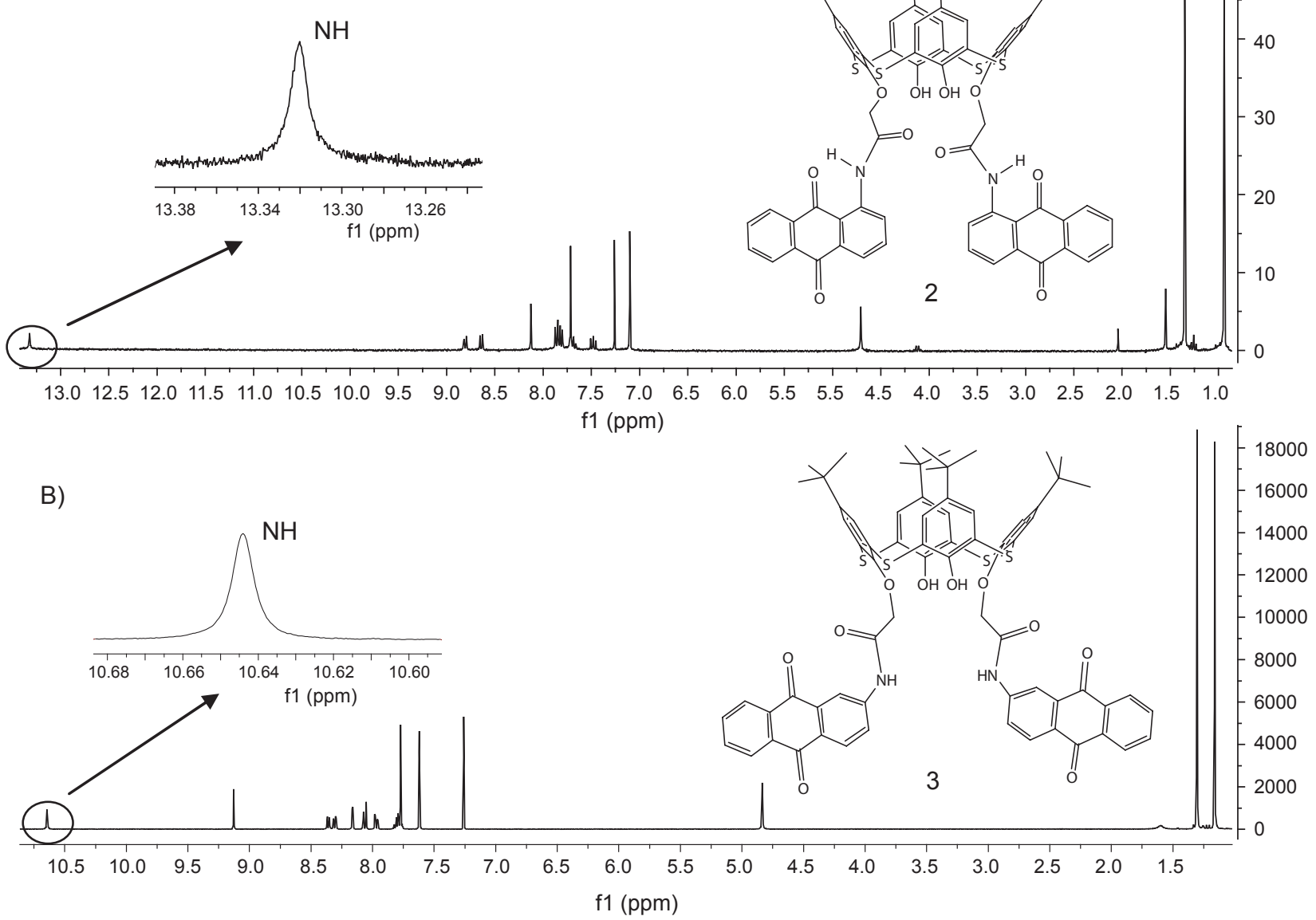

Figure. 1. ${ }^{1} \mathrm{H}$ NMR spectra and their fragments in the amide NH protons region of compound 2 (A) and $\mathbf{3}(\mathrm{B})\left(\mathrm{CDCl}{ }_{3}\right.$, at $25^{\circ} \mathrm{C}, \mathrm{Bruker}$ Avance-400). 


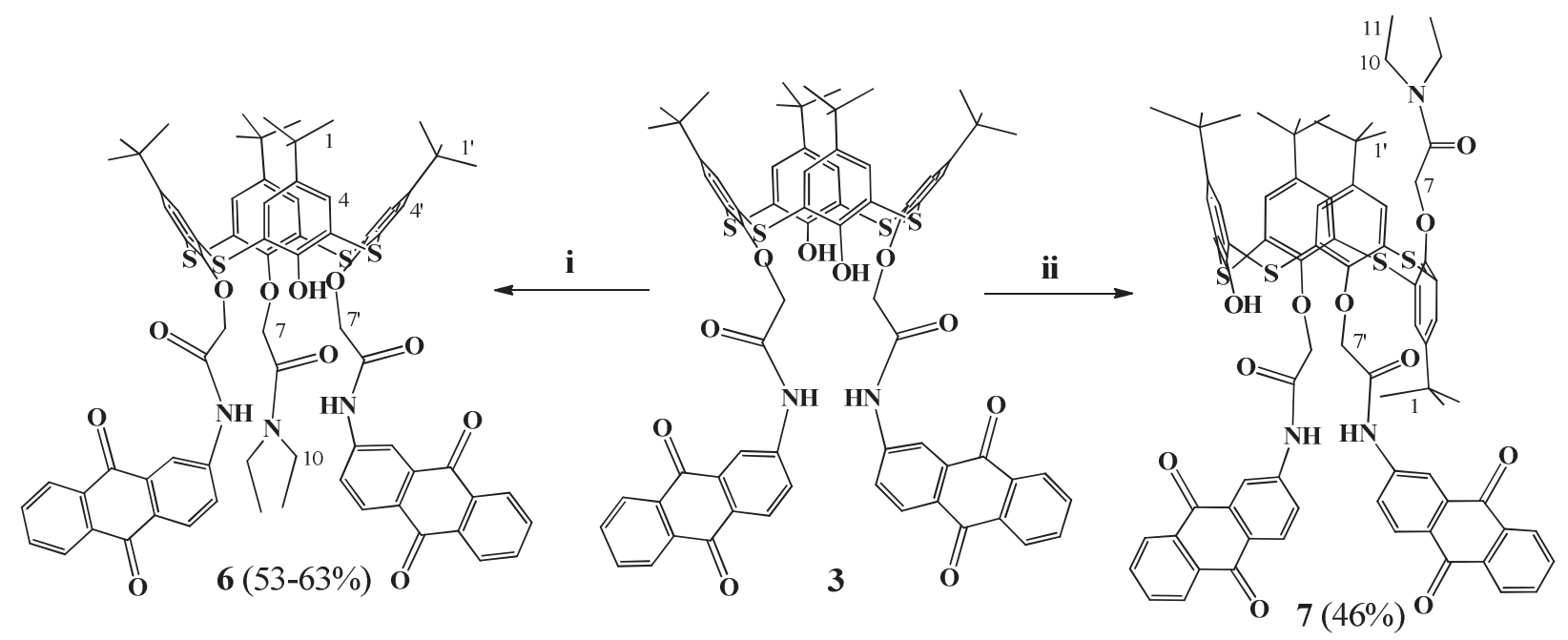

Scheme 3. Reagents and conditions: i, 2-chloro- $N, N$-diethylacetamide/ $\mathrm{Na}_{2} \mathrm{CO}_{3}$ or $\mathrm{K}_{2} \mathrm{CO}_{3}$, acetone, reflux; ii, 2-chloro- $N, N$ diethylacetamide/ $\mathrm{Cs}_{2} \mathrm{CO}_{3}$, acetone, reflux.

pounds $\mathbf{2}$ and $\mathbf{3}$ emit moderate green fluorescence (emission maximum are 570 and $580 \mathrm{~nm}$ for compounds $\mathbf{2}$ and $\mathbf{3}$, respectively). The introduction of two $N, N$-diethylacetamide fragments into compound $\mathbf{2}$ which are located on the opposite side of the macrocycle from the anthraquinone groups (1,3-alternate conformation, compound 5) leads to a significant increase in emission intensity and a shift of the emission maximum to the blue field, $497 \mathrm{~nm}$. This is explained by the fact that the anthraquinone fragments are fluorophores characterized by excited-state intramolecular proton transfer $(\text { ESIPT })^{[1,21]}$ which is presented by the decrease in fluorescence intensity and a significant Stokes shift in longer wavelengths. The proximity of acidic phenolic hydroxyl groups to the amide fragment in compound 2 leads to the protonation of the nitrogen atom, which further distorts conjugation thus increasing the ESIPT effect. The disappearance of the hydroxyl group as a result of substituting protons by the $\mathrm{N}, \mathrm{N}$ diethylacetamide fragments in compound $\mathbf{5}$ decreases the ESIPT, resulting in a significant blue shift of the emission peak and an increase in the intensity of emissions compared to the parent compound 2 . Introduction of additional $N, N$-diethylacetamide fragments, in the case of 2-amidoanthraquinone derivative $\mathbf{3}$, also leads to a significant increase in fluorescence. It is interesting that the spatial orientation of $N, N$ diethylacetamide groups relative to the macrocyclic platform has a significant effect on the emission of compounds 6 and

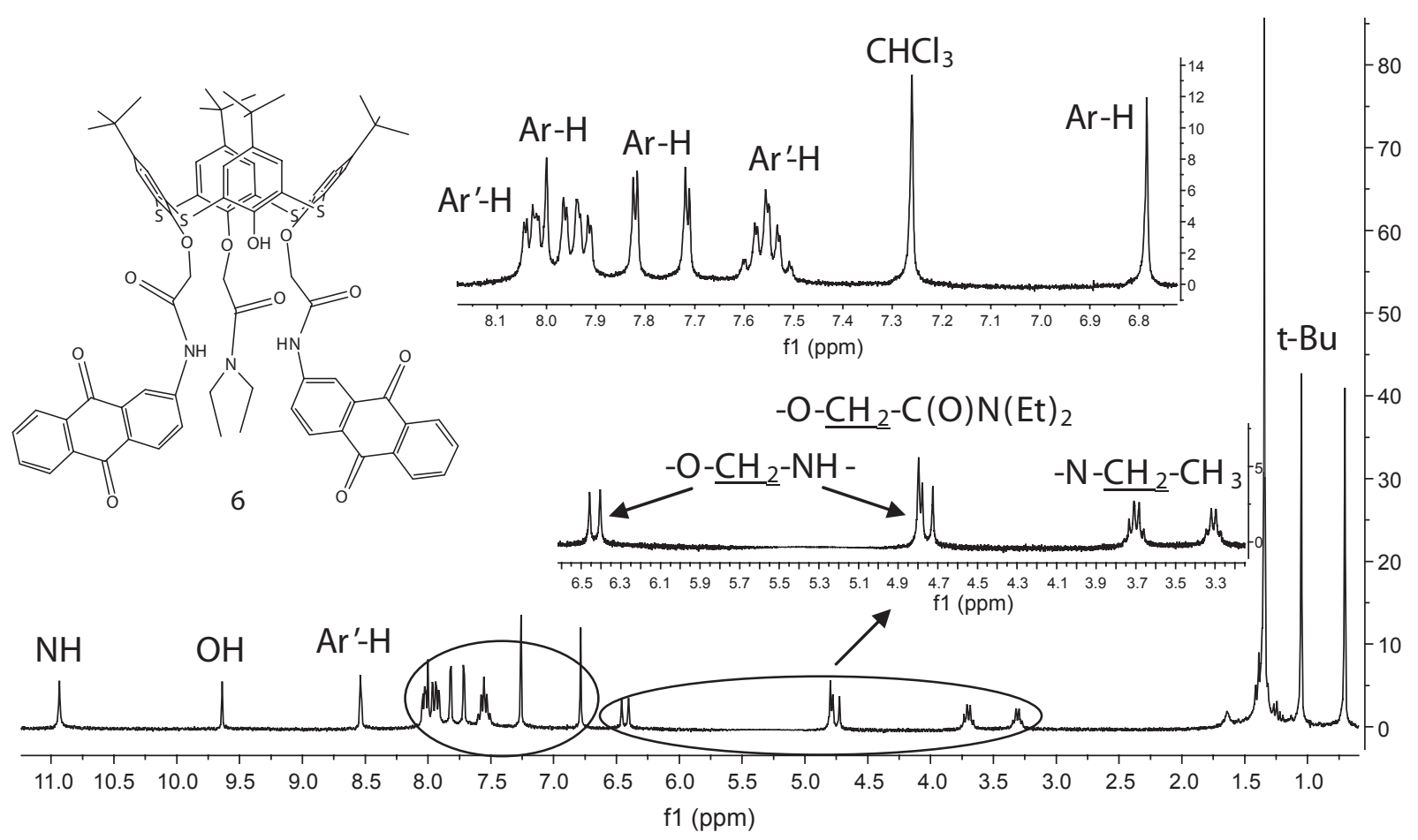

Figure. 2. ${ }^{1} \mathrm{H}$ NMR spectrum of compound $6\left(\mathrm{CDCl}_{3}\right.$, at $25^{\circ} \mathrm{C}$, Bruker Avance-400). 


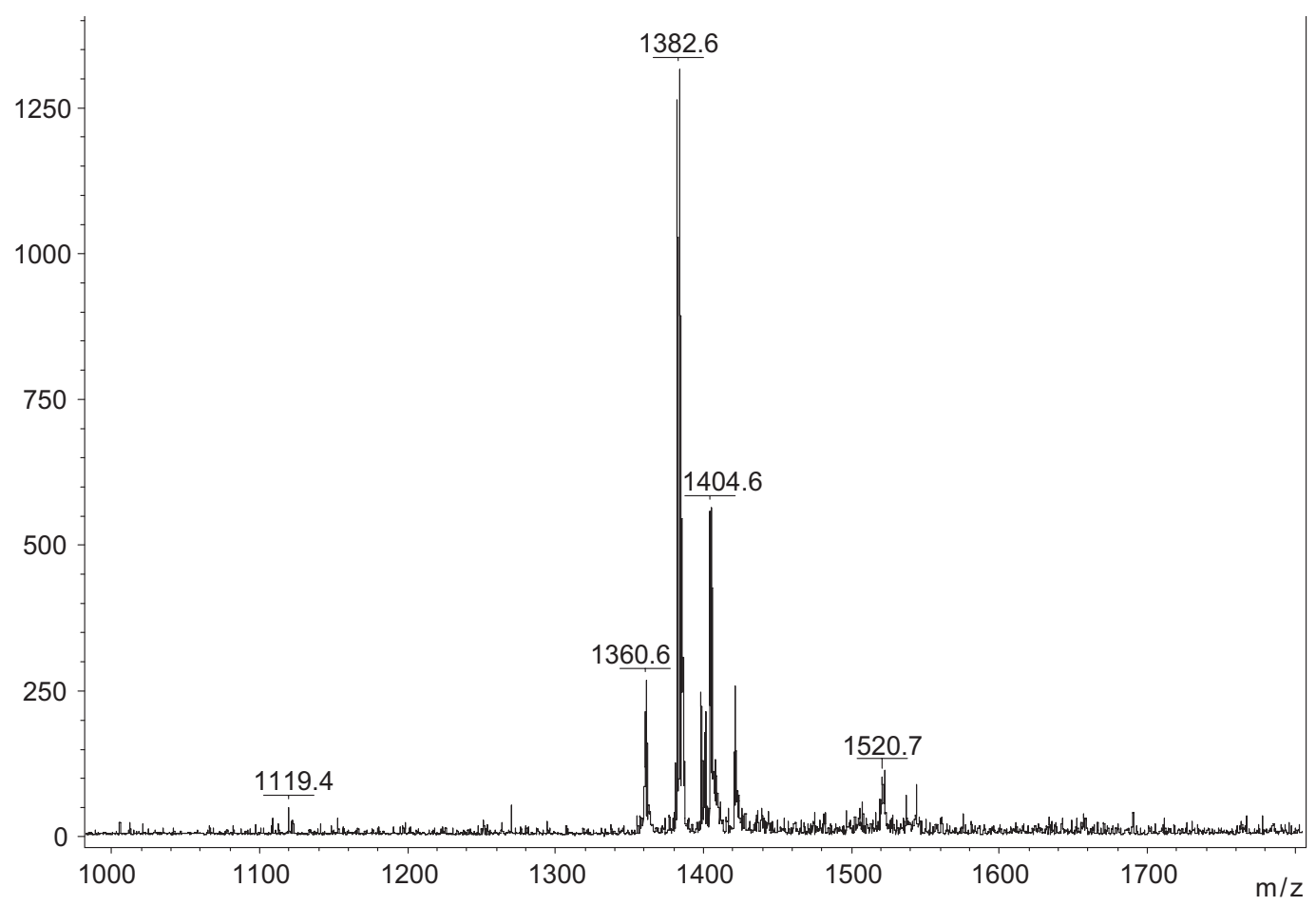

Figure. 3. MALDI-TOF mass spectrum of compound 7.

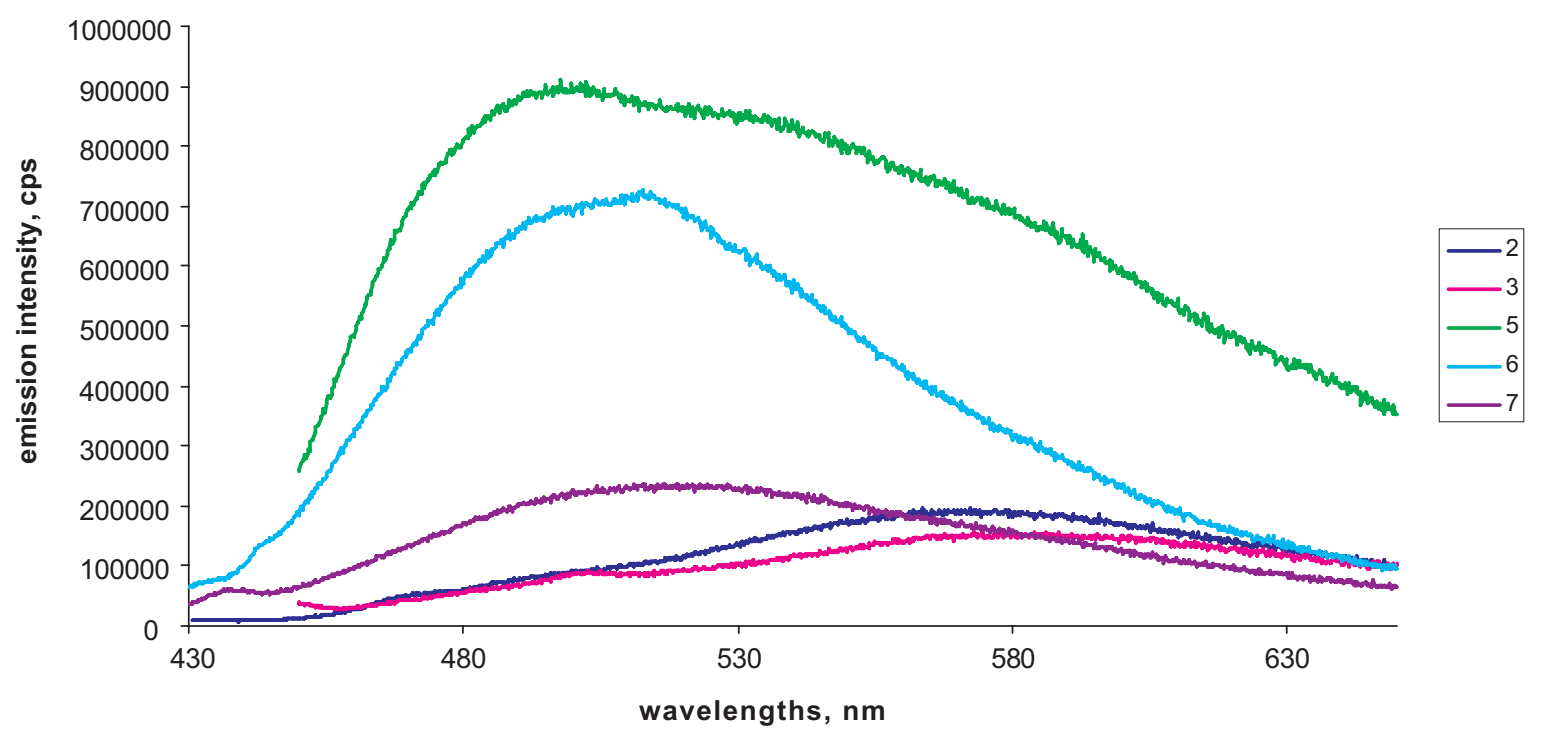

Figure. 4. The fluorescence spectra of thiacalix[4] $\operatorname{arenes} \mathbf{2 , 3}, \mathbf{5 - 7}\left(\mathrm{CDCl}_{3}, C=2.5 \cdot 10^{-5} \mathrm{M}, 25^{\circ} \mathrm{C}\right)$.

7. Thus, in thecase of the cone conformation which has all groups closer to each other in space, the emission maximum intensity of compound $\mathbf{6}$ at $512 \mathrm{~nm}$ is four times higher than the fluorescence intensity of the partial cone conformation of compound $7(517 \mathrm{~nm})$. This is explained by the fact that in compound $\mathbf{6}$ in the cone conformation, the retained hydroxyl group (in the case of compounds 6 and 7) is in close proximity in space with the strong proton acceptor $N, N$-diethylacetamide fragment, thus it becomes hydrogen-bonded to the carbonyl group which reflects the significant increase in emission intensity compared to compound 7.

\section{Conclusion}

Thus, new differently substituted at the lower rim p-tert-butyl thiacalix[4]arenes containing anthraquinone and tertiary amide groups were synthesized. It was shown that the chemo- and stereoselective alkylation of the lower rim 1,3-disubstituted $p$-tert-butyl thiacalix[4]arenes in the cone conformation using 2-chloro- $N, N$-diethylacetamide is determined by both the nature of the base and the position of the anthraquinone fragment in relation to the amide group: in the case of the 1-amidoanthraquinone derivative, 
tetrasubstituted products are formed, and in the case of the 2-amidoanthraquinone derivative - trisubstituted macrocycles are formed. Spectral properties of the obtained macrocycles were studied by fluorescence spectroscopy. It was established that the introduction of $N, N$-diethylacetamide fragments in the structure of anthraquinone thiacalix[4]arene derivatives leads to an increase in the fluorescence intensity and a significant hypsochromic shift of the fluorophore absorption maximum.

Acknowledgements. The work was supported by the Federal Program "Research and scientific-pedagogical personnel of innovative Russia” for 2009-2013 (№16.740.11.0472 on $13^{\text {th }}$ May 2011), RFBR (12-03-31314 mol a, 12-03-90414Ukr_a).

\section{References}

1. Jung H.S., Kim H.J., Vicens J., Kim J.S. Tetrahedron Lett. 2009, 50, 983-987.

2. Ni X.L., Zeng X., Redshaw C., Yamato T. Tetrahedron 2011, 67, 3248-3253.

3. Kas M., Lang K., Stibor I., Lhotak P. Tetrahedron Lett. 2007, 48, 477-481.

4. Stoikov I.I., Smolentsev V.A., Antipin I.S., Habicher W.D., Gruner M., Konovalov A.I. Mend. Comm. 2006, 16, 294-297.

5. Miao R., Zheng Q.Y., Chen Ch.F., Huang Zh.T. Tetrahedron Lett. 2005, 46, 2155-2158.

6. Vavilova A.A., Mostovaya O.A., Nosov R.V., Yagarmina A.N., Stoikov I.I. Butlerov Communication 2012, 32, 1-7.
7. Vavilova A.A., Mostovaya O.A., Nosov R.V., Yagarmina A.N., Stoikov I.I. Butlerov Communication 2012, 29, 8-12.

8. Solov'eva S.E., Omran A.O., Gruener M., Habicher W.D., Antipin I.S., Konovalov A.I. J. Struct. Chem. 2006, 46, 16-21.

9. Stoikov I.I., Zhukov A.Yu., Agafonova M.N., Sitdikov R.R., Antipin I.S., Konovalov A.I. Tetrahedron 2010, 66, 359-367.

10. Stoikov I.I., Mostovaya O.A., Yakimova L.S., Yantemirova A.A., Antipin I.S., Konovalov A.I. Mend. Comm. 2010, 20, 359-360.

11. Stoikov I.I., Yantemirova A.A., Nosov R.V., Rizvanov I.Kh., Julmetov A.R., Klochkov V.V., Antipin I.S., Konovalov A.I., Zharov I. Org. Biomol. Chem. 2011, 9, 3225-3234.

12. Stoikov I.I., Yantemirova A.A., Nosov R.V., Julmetov A.R., Klochkov V.V., Antipin I.S., Konovalov A.I. Mend. Comm. 2011, 21, 41-43.

13. Stoikov I.I., Yushkova E.A. Langmuir 2009, 25, 4919-4928.

14. Stoikov I.I., Yushkova, E.A., Zharov I.,Antipin I.S., Konovalov A.I. Tetrahedron 2009, 65, 7109-7114.

15. Stoikov I.I., Mostovaya O.A., Yantemirova A.A., Antipin I.S., Konovalov A.I. Mend. Comm. 2012, 22, 21-22.

16. Vavilova A.A., Meleshina M.V., Gorbachuk V.V., Yakimova L.S., Stoikov I.I. Butlerov Communication 2012, 31, 18-24.

17. Stoikov I.I., Yushkova E.A., Antipin I.S., Konovalov A.I. Journal of Nanoparticle Research 2011, 13, 6603-6611.

18. Han D.Y., Kim J.M., Kim J., Jung H.S., Lee Y.H., Zhang J.F., Kim J.S. Tetrahedron Lett. 2010, 51, 1947-1951.

19. Lakowicz J.R. Principles of Fuorescence Spectroscopy. New York: Kluwer Academic/Plenum Publishers, 1999. 698 p.

20. Iki N., Narumi F., Fujimoto T., Morohashi N., Miyano S. J. Chem. Soc. Perkin Trans. 1998, 2, 2745-2750.

21. Catalan J., Fabero F., Guijarro M.S., Claramunt R.M., Maria M.D.S., Foces-Foces M.C., Cano F.H., Elguero J., Sastre R. J. Am. Chem. Soc. 1990, 112, 747-759. 